\title{
The Effect of Digital Stories on Academic Achievement: A Meta-Analysis
}

\author{
Muhterem AKGÜN ${ }^{1}$ \& İsmail Hakan AKGÜN ${ }^{2}$ \\ ${ }^{1}$ Institute of Education Sciences, Firat University, Elazı ğ, Turkey \\ ${ }^{2}$ Faculty of Education, Adiyaman University, Adıyaman, Turkey \\ Correspondence: Muhterem AKGÜN, Institute of Education Sciences, Firat University, Elazı̆̆, Turkey. E-mail: \\ makgun27@gmail.com
}

Received: September 14, 2020 Accepted: October 20, 2020 Online Published: November 12, 2020

doi:10.5539/jel.v9n6p71 URL: https://doi.org/10.5539/jel.v9n6p71

\begin{abstract}
The purpose of this study is to determine the effect of digital stories on academic achievement. In order to achieve this purpose, meta analysis method was used in the study. Within the scope of the study, ERIC, Google Academic, YÖK Thesis Center, ProQuest, Science Direct and ULAKBİM databases were scanned and 23 studies (10 theses, 13 articles) were included in the meta-analysis using the criteria determined by the researchers. Cochran's $X^{2}(Q=285,155, p<.05)$ test was conducted to test whether the studies included in the study were heterogeneous. Random effects model was used to calculate effect size since heterogeneity was determined between studies. At the end of the study, it was seen that the general effect size (Hedge's g $=1.081$ ) regarding the effect of digital stories on academic achievement was strong, that there was a positive effect in all areas according to the lessons which was higher for Science. It was also observed that the effect was positive in all dimensions according to the education level, there was a difference between the education levels and the highest effect occurred at university and middle school levels.
\end{abstract}

Keywords: digital story, technology, digital technology, meta analysis

\section{Introduction}

Our age is known as the age of information; countries all over the world make an intense effort to become an information society, aiming to raise individuals who have the ability to learn how to learn (Keser, 2011). In the 21 st century, which is defined as the information age, the rapid developments in technology take all societies to a world where information is intense; accordingly, education programs, investments in education and education policies take a form in which more information is stored. In this context, educators have to develop new educational programs and learning/teaching models (İşman, 2011). Prensky (2001) describes today's students as digital natives and states that e-mail, internet, mobile phone, computer game and instant messaging are integral parts of their lives. In other words, children growing up with digital technology see technology as a tool rather than a barrier to learning (France \& Wakefield, 2011).

While the word 'story' is defined as "the event described in detail" by the Turkish Language Association [TDK] (2020), according to Işitan and Turan (2014), storytelling is one of the oldest arts and people have used this method to express themselves since the day they existed. With the advancing technology, classical methods have ceased to be the focus of attention of students and students' expectations from education have changed. Therefore, it can be said that using new and different methods and materials in parallel with the developing technology will increase the efficiency in education (Uslupehlivan, Kurtoğlu Erden, \& Cebesoy, 2017).

Digital storytelling consists of creating a narrative using personal digital media (e.g., photos, video, etc.) and detailing it with personal experience to show the narrative. The digital story offers the opportunity to write and record a script, edit digital photos and videos, and combine these media to create a coherent personal story (Landry \& Guzdial, 2006). When the definitions related to digital stories are examined in general, it is seen as combining the art of storytelling with various digital multimedia such as image, sound and video. Almost all digital stories consist of a mix of digital graphics, text, recorded voice narration, video and music to present information on a particular subject. Stories usually take only a few minutes to tell and are used to tell personal tales, historical events or to inform or instruct on a particular topic (Robin, 2006). Digital story is the process of 
integrating traditional literature (listening, reading, speaking, writing) with digital images, video, music and computer graphics (Bandi-Rao \& Sepp, 2014). According to Inceelli (2005), "digital storytelling is the process of presenting the purposeful narrative that enables the users in an interactive digital environment by giving the control of this environment; that enables them to discover their own knowledge and to apply this knowledge in real life situations; that enables the users to construct information in his mind in a meaningful way and to reinforce it with exercises and applications while moving in a story flow; and that uses multimedia applications such as sound, picture, graphics, motion graphics, images, music, text, photography, animation in addition to the narrator's own voice for information, education, entertainment purposes". As a teaching tool, teachers have the option to show their students preformed digital stories to grab students' attention while presenting content and new ideas (Robin, 2009). Digital stories are an important educational tool that develops students' creativity skills and prepares them a collaborative and social learning environment (Robin, 2016).

There have been numerous studies conducted in Turkey and around the world related to the effects of digital stories on writing skills (Baki \& Feyzioğlu, 2017; Demir \& Kılıçkıran, 2018; Çıralı, 2014; Dayan \& Girmen, 2018; Baki, 2019), attitude (Torun, 2019; Pürbudak \& Usta, 2019; Gömleksiz \& Pullu, 2017; Nam, 2017; Miyaji, 2012), motivation (Demir, 2019; Aktaş \& Yurt, 2017; Yoon, 2013; Hung et al., 2012; Kubravi et al., 2018; Bratitsis et al., 2012; Liu et al., 2018;), critical thinking (Ünlü \& Yangın, 2020; Akyeampong, 2018; Abdel-Hack \& Helwa, 2002; Chan, 2019), computational thinking (Kordaki \& Kakavas, 2017; Holt, 2011) and value acquisition (Kutlucan, Çakır, \& Ünal, 2018; Yürük \& Atıc1, 2017). In addition, there are applications of digital stories in foreign language education (Tatlı \& Aksoy, 2017; Tabak, 2017; Pürbudak \& Usta, 2019; Dollar \& Tolu, 2015; Ramírez Verdugo, \& Alonso Belmonte, 2007; Sancar Tokmak \& Yanpar Yelken, 2015; Gabarre, Din, \& Gabarre, 2011), teacher education (Uslupehlivan, Erden, \& Cebesoy, 2017; Tatlı \& Bayramoğlu, 2015; Özpınar, 2017; Demirer \& Baki, 2018; Kabaran et al., 2019), Turkish education (Dayan \& Girmen, 2018; Ertem et al., 2018, Yılmaz et al., 2017; Keleş, 2018), and preschool level (Gözen \& Cırık, 2017; Yüksel, 2011). However, no meta-analysis study on the effect of digital stories on academic achievement has been found in the literature. Meta-analysis studies are important for summarizing all studies in a field. Therefore, this study is thought to contribute to the field in terms of making a general judgment about the effect of digital stories on academic achievement.

\subsection{Purpose of the Study}

The aim of this study is to determine the effect of digital stories on academic achievement using meta-analysis. In this context, following research questions were asked:

What are the effects of digital stories on academic achievement?

Do the effects of digital stories on academic achievement vary by learning area?

Do the effects of digital stories on academic achievement vary by education level?

\section{Method}

In this study, meta-analysis method was used to determine the effect of digital stories on academic achievement. Dinçer (2014) defined meta-analysis as "grouping similar studies on a subject, theme or field of study under certain criteria and combining quantitative findings of these studies and interpreting them". Meta-analysis is a meaningful synthesis of the analysis results collected systematically (Borenstein et al., 2011). It adds a new dimension to the criticism by examining the findings of different studies altogether (Akgöz et al., 2004). Meta-analysis is the synthesis of the findings obtained from many experimental studies and can be used in many fields such as social sciences and medical sciences (Wolf, 1986). It creates a meaningful summary of many studies with effect size values (Hedges et al., 1999). The statistical meta-analysis method can be used to combine two or more individual study results. More specifically, an overall effect is estimated by calculating the mean of the weighted estimates in individual studies. There are several meta-analysis methods that differ mainly in the weighting scheme used. Meta-analysis provides a statistical method for evaluating the direction and size of the effect, and includes the question of whether the effect is consistent in different studies (Schwarzer, 2007). Meta-analysis is an assessment list to evaluate different studies that have quantitative data (Hedges \& Olkin, 2014).

\subsection{Data Collection}

After the research topic has been determined, a criterion has been determined for the studies to be included in the meta-analysis. These criteria can be listed as follows:

- The study should be conducted between 2010-2020 
- The studies should be articles published in refereed journals or master/doctoral theses

- The studies should be in Turkish or in English

- The studies should be experimental studies and should have experimental and control groups

- The required values for calculations of effect size (X, ss, F, p...) should be given in the study.

Between 15.04.2020-15.08.2020, the keywords of "dijital öykü AND başarı" (Turkish for digital narrative AND achievement), "dijital hikaye AND başarı" (Turkish for digital story AND achievement), "digital story AND achievement", "digital storytelling AND achievement", "digital story AND performance" were searched in the databases of ERIC, Google Scholar, YÖK Thesis Center, ProQuest, Science Direct, ULAKBİM, and initially 35 studies were downloaded. Later, it was determined that 5 studies were articles produced from theses and some of the other studies did not provide sufficient information for analysis or were not suitable for meta-analysis. As a result, 23 studies were included in the meta-analysis.

\subsection{Coding of the Studies}

The studies included in the study were processed in an Excel table containing the name of the author(s), publication year, field, participants' grade level, statistical methods and data required for meta-analysis $(X, \mathrm{ss}, \mathrm{N}$, $\mathrm{p}, \mathrm{F}$, etc.). In order to calculate the reliability coefficient of the study, a comparison was made after the studies were coded separately by the researchers. According to the formula suggested by Miles and Huberman (1994) (Consensus/[Consensus + Disagreement]), the coefficient of congruence of the codes was found to be $95 \%$. Yıldırım and Şimşek (2006) state that in order to ensure reliability in such studies, at least $70 \%$ compliance is required. Therefore, it can be said that the reliability of the study is high. Information about the studies included in meta-analysis is presented in Table 1.

Table 1. Information on the studies included in the meta-analysis

\begin{tabular}{lll}
\hline & Variables & $\mathrm{n}$ \\
\hline Type of study & Master Thesis & 8 \\
& PhD Thesis & 2 \\
& Journal Article & 13 \\
Grade level & Preschool & 1 \\
& Elementary School & 5 \\
& Middle School & 11 \\
& High School & 3 \\
$\mathrm{~N}_{\text {Experiment }}$ & University & 3 \\
$\mathrm{~N}_{\text {Control }}$ & & 907 \\
\hline & & 889 \\
\hline
\end{tabular}

When Table 1 is examined, it is seen that the studies included in the meta-analysis consist of 8 master theses, 2 doctoral theses, and 13 articles published in refereed journals. It is also seen that 1 of the studies were carried out with preschool students, 5 with elementary school students, 11 with secondary school, 3 with high school and 3 with university students.

\subsection{Data Analysis}

For data analysis, firstly the data required for meta-analysis were processed into a form in Microsoft Excel format. Comprehensive Meta-Analysis (CMA) program was used for the analyses. Data entry into the coding form was made by two researchers separately and then two entries were compared. In this way, errors related to data entry were prevented.

In this study, funnel plot, Rosenthal's Safe N Theory and Correlation Rank methods of Begg and Mazumdar (1994) were used for calculating publication bias. The funnel plot is based on the idea that as the sample size of the studies increases, the precision in estimating the effect will increase, and studies with a small sample will be widely distributed at the bottom of the graph and the distribution among larger studies will narrow. The situation where the drawing resembles a symmetrical inverted funnel indicates that there is no bias (Egger et al., 1997).

The most common way of expressing the extent of heterogeneity is using the statistical test known as Cochran's $\mathrm{X}^{2}$ test or $\mathrm{Q}$ test. A $\mathrm{p}$ value is frequently quoted as an indicator of the extent of variability between studies (Higgins \& Thompson, 2002). In this study, the $\mathrm{p}$ value and $\mathrm{Q}$ values for the heterogeneity test were examined and the calculated Q value was compared with the corresponding value in the $\mathrm{X}^{2}$ table. Finally, using the $\mathrm{I}^{2}$ value, 
it was checked whether the studies were heterogeneous.

Hedge's g was used at $95 \%$ confidence interval for the effect size calculation. In the evaluation of effect size, the classification determined by Cohen et al. (2007) has been taken into consideration.

Cohen et al. (2007) interpreted effect size value ranges as follows;

$\bullet 0 \leq$ Effect Size $\leq 0.20$, weak,

$\bullet .21 \leq$ Effect Size $\leq 0.50$, small,

$\bullet 0.51 \leq$ Effect Size $\leq 1.00$, medium,

$\cdot 1.01 \leq$ Effect Size, strong.

Since it was seen that there was a heterogeneous structure among the studies included in the meta-analysis according to the heterogeneity test performed in this study, Random Effects Model was used in the effect size calculation. When the literature is examined, it can be seen that there are two popular models; fixed effects and random effects models. Model selection is extremely important because besides affecting the calculations, the model helps to interpret the statistical results and to determine the aims of the analysis (Borenstein et al., 2010). Different studies may come from different populations, use different protocols, and have variables with different levels of confounding or modifying effects, and therefore may not share a common area of interest. In the presence of heterogeneity, the fixed effects model may underestimate the standard error of the point estimation by ignoring the variance between studies, and incorrect use of this model may produce false positive results (Chen et al., 2012). The random effects model allows for both within-study and between-study variances and is more prudent than the fixed effects model in affirming the importance of the effect size. In the presence of heterogeneity, the random effects model provides a more appropriate standard error of point estimation and a better confidence interval compared to the fixed effects model (Dempster et al., cited in Chen et al., 2012). The defining feature of the fixed effect model is that all studies included in the analysis share the common effect size; the defining feature of the random effects model is that it is a distribution of real effect sizes and the purpose is to predict the theme of this distribution (Borenstein et al., 2010).

\section{Results}

In this section, statistical results related to publication bias, heterogeneity and effect size will be presented.

\subsection{Findings Related to Publication Bias}

First, it was determined whether there was publication bias or not. The funnel chart created for this is presented in Figure 1.

\section{Funnel Plot of Standard Error by Hedges's $\mathrm{g}$}

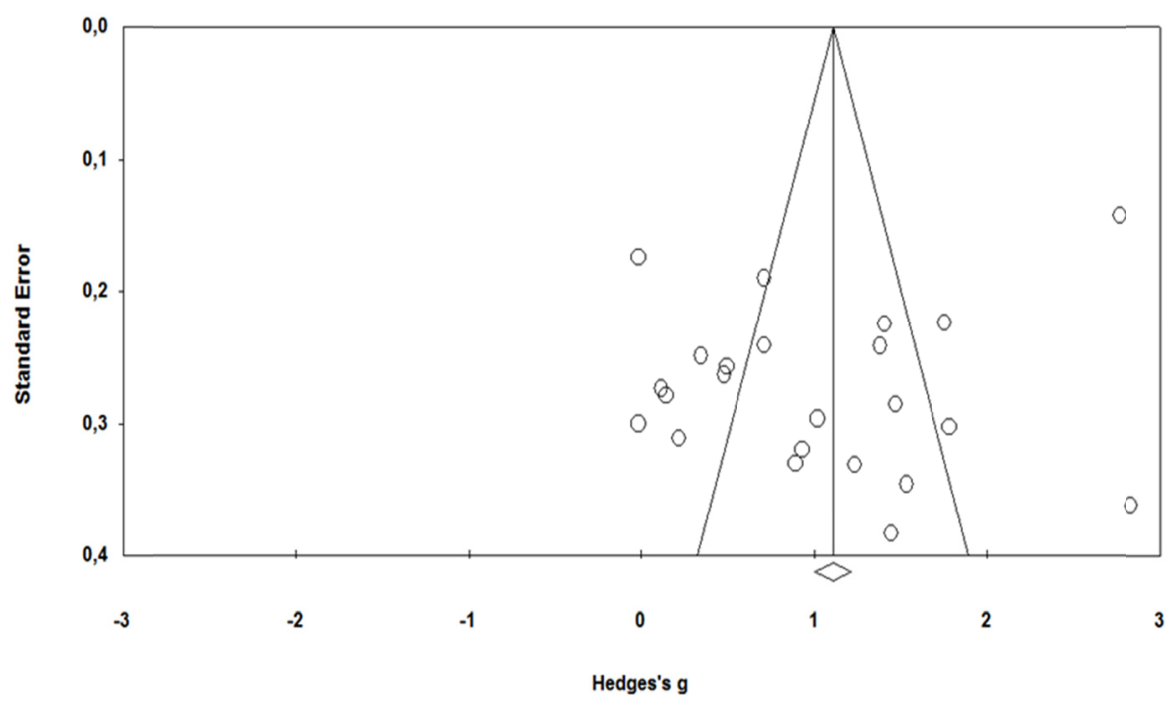

Figure 1. Publication bias 
In order to test publication bias, most of the publications in the graph are expected to gather symmetrically within the funnel lines and around the general effect line (Dinçer, 2014; Borenstein et al., 2011). When the graphic is examined, it is seen that most of the studies take place inside the funnel. However, there are points in the graph that are not symmetrical. There are studies with a small sample at the bottom of the funnel plot and large studies at the top (Dinçer, 2014). Accordingly, it can be said that the studies examined in this study are studies with small and large samples. From this graph, it can be said that 23 studies included in the study were close to show publication bias. There are also statistical procedures to detect publication bias one of which is Rosenthal's Protected N theory.

Table 2. Results of the studies included in the meta-analysis according to Rosenthal's Protected N Theory

\begin{tabular}{ll}
\hline Z-value for the Studies reviewed & 20.15214 \\
\hline p-value for the Studies reviewed & 0.0000 \\
Alpha & 0.05000 \\
Direction & 2.0000 \\
Z-value for alpha & 1.95996 \\
Number of Studies Reviewed & 23 \\
Safe N (Fail-safe Number) & 2409 \\
\hline
\end{tabular}

Rosenthal (1991; cited in Bakioğlu \& Göktaş, 2018) stated that when calculating the safe N number for the study obtained from $\mathrm{k}$ studies, if $\mathrm{N}>5 \mathrm{k}+10$, the meta-analysis findings would be quite strong. That is, according to this theory, it can be said that the farther the number of studies examined from the safe $\mathrm{N}$ number is, the less the study shows publication bias. In this case, it can be said that there is no publication bias in this study since it is $2409>5 * 23+10$.

Another statistic for publication bias is the Begg and Mazumdar Rank Correlation statistics. According to this statistic, it is accepted that there is no publication bias if the Tau coefficient is close to 1.00 and the two-tailed $p$ value is not significantly different (Begg \& Mazumdar, 1994).

Table 3. Begg and Mazumdar rank correlation statistics

\begin{tabular}{ll}
\hline Tau & 0.83000 \\
\hline Z-value for Tau & 0.55462 \\
P-value (One-tailed) & 0.28598 \\
P-value (Two-tailed) & 0.57915 \\
\hline
\end{tabular}

When Table 3 is examined, it can be said that there is no publication bias in this study since the Tau coefficient $(0.83000)$ is close to 1.00 and the p-value (two-tailed) is $>0.05$.

\subsection{Findings Related to Heterogeneity Test}

Before calculating the effect size, it was investigated whether the studies included in meta-analysis had a heterogeneous structure and the analysis method to be used was decided according to the heterogeneity test result.

Table 4. Heterogeneity test

\begin{tabular}{lllllll}
\hline $\begin{array}{l}\text { Overall Effect } \\
\text { Size }(\mathrm{g})\end{array}$ & $\begin{array}{l}\text { Degree of } \\
\text { Freedom }(\mathrm{df})\end{array}$ & $\begin{array}{l}\text { Heterogeneity } \\
\text { Value }(\mathrm{Q})\end{array}$ & $\mathrm{I}^{2}$ & $\mathrm{p}$ & \multicolumn{2}{c}{ Average Confidence Interval for Effect Size } \\
\cline { 5 - 6 } & 22 & 285.155 & 92.285 & .000 & 0.703 & EB $_{\text {Upper }}$ \\
\hline 1.081 & 22 & & & &
\end{tabular}

According to the heterogeneity test results, it was observed that the studies were different from each other, that there was a heterogeneous structure between the studies $(\mathrm{Q}=285.155, \mathrm{p}<.05)$ and the heterogeneity level $\left(\mathrm{I}^{2}\right)$ between the studies was determined as $92 \%$. An $\mathrm{I}^{2}$ value above $75 \%$ indicates a high level of heterogeneity (Cooper, Hedges, \& Valentin, 2009). According to Higgins and Thompson (2002), there is a positive correlation between the addition of different studies to the analysis and heterogeneity. According to this result, random effects model was preferred in the calculation of effect size in this study. 


\subsection{Findings Related to the Effect of Digital Stories on Academic Achievement}

Information about the general effect size obtained by using random effects model due to the heterogeneous nature of the studies included in the meta-analysis is given in Table 5.

Table 5. Overall effect size

\begin{tabular}{lllllll}
\hline Overall Effect Size $(\mathrm{g})$ & $\mathrm{N}$ & Standard Error (SE) & Variance & $\mathrm{Z}$ & $\mathrm{P}$ & \multicolumn{2}{l}{ Average Confidence Interval for Effect Size } \\
\hline 1.081 & 23 & 0.193 & 0.037 & 5.609 & 0.000 & $\begin{array}{l}\mathrm{EB}_{\text {Lower }} \\
\text { EB }\end{array}$ \\
& & & & & 0.703 & 1.459 \\
\hline
\end{tabular}

According to the information in Table 5, the general effect size of the effect of digital stories on academic success was determined as Hedge's $g=1.081$ according to the random effects model, and this value was determined as a strong effect size according to the classification made by Cohen et al. (2007). It can also be said that the effect size value shows a significant difference $(Z=5.609, p=0.000)$. According to this result, it can be concluded that digital stories have a strong positive effect on academic achievement in favor of the experimental group.

\subsection{The Effect of Digital Stories on Academic Achievement Based on Sub-Dimensions}

Table 6 contains meta-analysis results in terms of subject.

Table 6. The effect of digital stories on academic achievement by subject

\begin{tabular}{|c|c|c|c|c|c|c|c|}
\hline Model & \multirow[t]{2}{*}{$\mathrm{N}$} & \multirow[t]{2}{*}{ Hedge's g } & \multicolumn{2}{|c|}{ 95\% Confidence Interval } & \multirow{2}{*}{$\begin{array}{l}\text { Degree of freedom } \\
9\end{array}$} & \multicolumn{2}{|c|}{ Heterogeneity Test } \\
\hline Random Effects Model & & & Lower bound & Upper bound & & $Q_{\text {between }}$ & $\mathrm{p}$ \\
\hline Science & 6 & 1.562 & 0.975 & 2.149 & & 200.963 & 0.000 \\
\hline English & 4 & 0.846 & 0.100 & 1.593 & & & \\
\hline Mathematics & 2 & 0.254 & -0.225 & 0.734 & & & \\
\hline Social Studies & 3 & 0.686 & 0.384 & 0.987 & & & \\
\hline Turkish & 3 & 0.995 & 1.089 & 1.359 & & & \\
\hline
\end{tabular}

When Table 6 was examined, it was seen that there was a difference between the fields according to the statistical results regarding the effect of digital stories on academic achievement in terms of subject, and the largest effect was in the field of Science $(\mathrm{g}=1.562)$. The calculation could not be made due to the inadequacy of studies in the fields of Physics, Chemistry, Biology, Information and Communication Technologies and Morality. In the heterogeneity test conducted to determine whether the effect sizes differ between courses, the value of Qbetween $(200,963)$ was above the critical value (16.919) specified for the degree of freedom in the $\mathrm{X}^{2}$ table 9 at the $95 \%$ significance level and the $p$ value was less than $0.05(p=0.000)$. For this reason, it could be said that there was a heterogeneous structure among studies $\left(\mathrm{Q}_{\text {between }}=200,963 ; \mathrm{p}=0,000\right)$. In other words, it could be said that the field type was a variable that changed the effect size.

Table 7. The effect of digital stories on academic achievement by learning level

\begin{tabular}{|c|c|c|c|c|c|c|c|}
\hline Model & \multirow[t]{2}{*}{$\mathrm{N}$} & \multirow[t]{2}{*}{ Hedge's g } & \multicolumn{2}{|c|}{$95 \%$ Confidence Interval } & \multirow{2}{*}{$\begin{array}{l}\text { Degree of freedom } \\
4\end{array}$} & \multicolumn{2}{|c|}{ Heterogeneity Test } \\
\hline Random Effects Model & & & Lower bound & Upper bound & & $\mathrm{Q}_{\text {between }}$ & $\mathrm{p}$ \\
\hline Elementary School & 5 & 0.714 & 0.084 & 1.344 & & 81.390 & 0.000 \\
\hline Middle School & 11 & 1.092 & 0.663 & 1.520 & & & \\
\hline High School & 3 & 0.859 & -0.151 & 1.868 & & & \\
\hline College & 3 & 1.294 & 0.979 & 1.609 & & & \\
\hline
\end{tabular}

When Table 7 was examined, it was seen that according to the statistical results regarding the effect of digital stories on academic achievement in terms of education level, there was a significant difference according to education levels and the largest effect coefficient $(g=1.294)$ was found in university students. Since the $Q$ value (81.390) found in order to determine whether the effect sizes differ according to the education level was above the corresponding degree of freedom (4) in the $\mathrm{X}^{2}$ table and the critical value of 9.488 determined for the $95 \%$ significance level and the $\mathrm{p}$ value was less than 0.05 , it could be said that the distribution had a heterogeneous structure $\left(\mathrm{Q}_{\text {between }}=81.390 ; \mathrm{p}=0.000\right)$. In this case, it could be said that the education level changed the effect 
size.

\section{Discussion}

In this study, it was aimed to determine the effect of digital stories on academic achievement using meta-analysis method. In this context, 23 studies including 10 theses and 13 articles published in refereed journals were examined. In a study conducted by Talan (2019), it was also seen that the studies on digital stories were generally in the form of articles. While the studies examined in the current study mostly conducted at the middle school level (11), there were also studies at the elementary school (5), high school (3), university (3) and preschool (1) levels. According to Talan (2019), studies on digital stories were mostly conducted at middle school and university level. In the study conducted by Şimşek et al. (2018), it was found that digital stories were mostly used at university and middle school levels. It was observed that the studies included in the current meta-analysis were mostly conducted in fields such as Science, Turkish Education, Mathematics and Social Studies. In the study conducted by Talan (2019), Science, Turkish and Foreign Language were also the most common subjects.

In the study, funnel plot, Rosenthal's safe $\mathrm{N}$ theory and correlation tests of Begg and Mazumdar were applied to test publication bias. According to Rosenthal's safe $\mathrm{N}$ theory, it can be said that the farther the number of studies examined from the safe $\mathrm{N}$ number is, the less the study shows publication bias. In this case, it could be said that there was no publication bias in this study since $2409>5 * 23+10$. Another statistic for publication bias is the Begg and Mazumdar Rank Correlation statistic. According to this statistic, it is accepted that there is no publication bias if the Tau coefficient is close to 1.00 and the two-tailed $p$ value is not significantly different (Begg \& Mazumdar, 1994). Since the Tau coefficient (0.83000) in this study was close to 1.00 and the p-value (two-tailed) was $>0.05$, it could be said that there was no publication bias in this study.

According to the results obtained from the research, the effect of digital stories on academic achievement was found to be $g=1.081$ and this value is a high-level effect according to Cohen's (2007) classification. This result coincides with the meta-analysis studies conducted by Camnalbur (2008), Dinçer (2015), Dikmen and Tuncer (2018), Grgurovic et al. (2013), and $\mathrm{Li}$ and $\mathrm{Ma}$ (2010) in order to determine the effect of computer-aided education on academic achievement. Likewise, Cheung and Slav (2012), Schmid et al. (2009), Schmid et al. (2014), Tamim et al. (2014), and Cheung and Slav (2012) found a strong effect in their meta-analysis studies on the effect of technology use in education on academic achievement. In the meta-analysis study conducted by Lee (1999) on the effect of computer-aided simulations on academic achievement, it was found that there was a positive result in favor of the experimental group. In the meta-analysis study conducted by Orhan and Durak Men (2018) on the effect of web-based teaching on science achievement, it was seen that there was a high effect. A meta-analysis study by Ayaz et al. (2016) aimed at determining the effect of using instructional technology on the academic success of primary school students, and it was found that there was a moderate but close to high positive effect. Today, developments in the field of internet and technology have been reflected in educational environments and brought a new perspective. Information-media-technology literacy (Kotluk \& Kocakaya, 2015), which is a common feature in the studies of all organizations and which is defined as 21 st century skills by by organizations such as ISTE, P21 and as "survival skills" Wagner (2008), is also supported by digital stories (Robin, 2009).

In the current study, it was seen that the effect of digital stories on academic achievement according to the fields led to positive results in all dimensions and these values were evaluated as high effect according to Cohen's (2007) classification, and that there was a significant difference between the fields and the highest effect size value was in the field of Science. When the literature is examined, Ayaz et al. (2016) found that the highest effect occurred in the Social Studies course and there was no significant difference between the fields. In the meta-analysis study conducted by Camnalbur (2008) on the effectiveness of computer aided education, it was observed that there was a difference between the fields. In the study conducted by Kablan et al. (2013) on the use of materials in classroom teaching, the use of materials in the classroom had a positive effect in all areas, there was no difference between the fields and the highest effect value was in Science. This result may be due to the fact that the studies are mostly conducted in the field of Science. In the study conducted by Dinçer (2015), it was seen that the studies on computer-aided education were mostly conducted in the field of Science.

Another result obtained from the study showed that the effect of digital stories on academic achievement according to the education level was positive in all dimensions, there was a difference between education levels and the highest effect occurred at the university and middle school levels. In the study conducted by Cheung and Slav (2012), it was observed that there was a significant difference in favor of middle school students. On the other hand, in the study conducted by Wenglinsky (1998), it was observed that computer-aided education was 
more effective on elementary school students and a significant difference occurred.

\section{Suggestions}

In line with the findings of this research, the following recommendations can be developed:

- As a result of the meta-analysis, it was seen that the effect of digital stories on academic achievement was strong. Therefore, teachers can use digital stories to increase student success in the educational environment.

- It has been determined that studies on the effect of digital stories on academic achievement are mostly conducted at the middle school level. By doing more studies in other education levels, healthier results regarding the effect size can be obtained in future meta-analysis studies compared to the education levels.

- It has been determined that studies on the effect of digital stories on academic achievement are mostly carried out in the field of Science. For some courses, the calculation could not be made because there was not enough research. By conducting studies in different fields, the effect size can be calculated for other courses in future meta-analysis studies.

- Meta-analysis studies can be conducted on the effects of digital stories on motivation, self-efficacy and collaborative learning, etc.

- More studies can be done to include more studies in future meta-analysis studies.

\section{References}

Abdel-Hack, E. M., \& Helwa, H. S. A. H. A. (2002). Using digital storytelling and weblogs instruction to enhance EFL narrative writing and critical thinking skills among EFL majors at faculty of education. Narrative, 2004(2002).

Akgöz, S., Ercan, İ., \& KAN, İ. (2004). Meta-analizi. Uludağ Üniversitesi Tıp Fakültesi Dergisi, 30(2), 107-112.

Akgül, G. (2018). Fen ve teknoloji dersinde dijital öyküleme sürecinde yaratıcı drama kullanımının başarı, tutum ve bilimsel yaratıcılı̆̆a etkisi. Yüksek lisans tezi. Mersin Üniversitesi, Eğitim Bilimleri Enstitüsü. https://doi.org/10.24106/kefdergi.3379

Aktas, E., \& Yurt, S. U. (2017). Effects of digital story on academic achievement, learning motivation and retention among university students. International Journal of Higher Education, 6(1), 180-196. https://doi.org/10.5430/ijhe.v6n1p180

Akyeampong, A. S. (2018). Promoting creativity and critical thinking through digital storytelling: Perceptions of undergraduate students. In Educational technology and narrative (pp. 271-282). Springer, Cham. https://doi.org/10.1007/978-3-319-69914-1_22

Aljaraideh, Y. A. (2020). The Impact of Digital Storytelling on Academic Achievement of Sixth Grade Students in English Language and Their Motivation towards It in Jordan. Turkish Online Journal of Distance Education, 21(1), 73-82. https://doi.org/10.17718/tojde.690345

Ayaz, M. F., Şekerci, H., \& Behçet, O. (2016). Öğretim Teknolojileri Kullanımının İlkokul Öğrencilerinin Akademik Başarılarına Etkisi: Bir Meta-Analiz Çalışması. İnönü Üniversitesi Eğitim Fakültesi Dergisi, 17(1). https://doi.org/10.17679/iuefd.17294446

Baki, Y. (2019). Türkçe Öğretmeni Adaylarının Yaratıcı Yazma Becerilerinin Geliştirilmesinde Dijital Öykülerin Etkisi. Ana Dili Eğitimi Dergisi, 7(4), 964-995. https://doi.org/10.16916/aded.597269

Baki, Y., \& Feyzioğlu, N. (2017). Dijital Öykülerin 6. Sınıf Öğrencilerinin Öykü Yazma Becerilerine Etkisi. International Online Journal of Educational Sciences, 9(3).

Bakioğlu, A., \& Göktaş, E. (2018). Bir Eğitim Politikası Belirleme Yöntemi: Meta analiz. Medeniyet Eğitim Araştırmaları Dergisi, 1(2), 35-54.

Bandi-Rao, S., \& Sepp, M. (2014). Designing a digital story assignment for basic writers using the TPCK framework. Journal of Basic Writing, 103-123.

Begg, C. B., \& Mazumdar, M. (1994). Operating Characteristics of a Rank Correlation Test for Publication Bias. Biometrics, 1088-1101. https://doi.org/10.2307/2533446

Bilen, K., Hoştut, M., \& Büyükcengiz, M. (2019). The effect of digital storytelling method in science education on academic achievement, attitudes, and motivations of secondary school students. Pedagogical Research, 4(3), em0034. https://doi.org/10.29333/pr/5835

Borenstein, M., Hedges, L. V., Higgins, J. P., \& Rothstein, H. R. (2010). A basic introduction to fixed - effect 
and random-effects models for meta-analysis. Research Synthesis Methods, 1(2), 97-111. https://doi.org/10.1002/jrsm.12

Borenstein, M., Hedges, L. V., Higgins, J. P., \& Rothstein, H. R. (2011). Introduction to meta-analysis. John Wiley \& Sons.

Bratitsis, T., Kotopoulos, T., \& Mandila, K. (2012). Kindergarten children's motivation and collaboration being triggered via computers while creating digital stories: A case study. International Journal of Knowledge and Learning, 8(3-4), 239-258. https://doi.org/10.1504/IJKL.2012.051677

Büyükcengiz, M. (2017). Dijital öyküleme metodunun ortaokul öğrencilerinin fen bilimleri dersi akademik başarl, bilimsel süreç becerileri ve derse yönelik tutumlarına etkisi. Yayımlanmamış yüksek lisans tezi. Akdeniz Üniversitesi, Eğitim Bilimleri Enstitüsü, İstanbul.

Çakıcı, L. (2018). Dijital Öykü Temelli Matematik Öğretiminin Öğrencilerin Akademik Başarı Motivasyon ve Matematik Etkinliklerine Yönelik Tutumları Üzerine Etkisi. Yayımlanmamış Yüksek Lisans Tezi. Gaziantep Üniversitesi, Eğitim Bilimleri Enstitüsü.

Camnalbur, M. (2008). Bilgisayar destekli öğretimin etkililiği üzerine bir meta analiz çalışması. Yayımlanmamış yüksek lisans tezi. Marmara Üniversitesi, Eğitim Bilimleri Enstitüsü.

Chan, C. (2019). Using digital storytelling to facilitate critical thinking disposition in youth civic engagement: A randomized control trial. Children and Youth Services Review, 107, 104522. https://doi.org/10.1016/j.childyouth.2019.104522

Chen, H., Manning, A. K., \& Dupuis, J. (2012). A method of moments estimator for random effect multivariate meta - analysis. Biometrics, 68(4), 1278-1284. https://doi.org/10.1111/j.1541-0420.2012.01761.x

Cheung, A. C., \& Slavin, R. E. (2012). How features of educational technology applications affect student reading outcomes: A meta-analysis. Educational Research Review, 7(3), 198-215. https://doi.org/10.1016/j.edurev.2012.05.002

Çıralı, H. (2014). Dijital hikâye anlatımının görsel bellek ve yazma becerisi üzerine etkisi. Yayımlanmamış Yüksek Lisans Tezi. Hacettepe Üniversitesi: Ankara.

Cohen, L., Manion, L., \& Morrison, K. (2007). Research methods in education. Routledge. https://doi.org/10.4324/9780203029053

Cooper, H., Hedges, L. V., \& Valentine, J. C. (2009). The handbook of research synthesis and meta-analysis (2nd ed.). Sage Publication.

Dayan, G., \& Girmen, P. (2018). Türkçe Eğitimi Yazma Sürecinde: Dijital Öyküleme. Eğitimde Nitel Araştırmalar Dergisi, 6(3), 207-228.

Demir, S., \& Kılıçkıran, H. (2018). Dijital öykü uygulamasının özel yetenekli öğrencilerin yazma becerilerine etkisi. Disiplinlerarası Ĕgitim Araştırmaları Dergisi, 2(4), 12-18.

Demir, T. (2019). Dijital öykülerin ilkögretim 5. sınıf ögrencilerinin motivasyon, tutum ve başarılarına etkisi. Yayımlanmaımş Yüksek lisans Tezi. Balıkesir Üniversitesi Sosyal Bilimler Enstitüsü.

Demirbaş, İ. (2019). Dijital Öykülerin İlkokul Öğrencilerinin Dinlediğini Anlama ve Yaratıcı Yazma Becerilerine Etkisi. Yayımlanmamış Yüksek Lisans Tezi. Kırşehir Ahi Evran Üniversitesi, Sosyal Bilimler Enstitüsü.

Demirer, V., \& Baki, Y. (2018). Türkçe öğretmeni adaylarının dijital öyküleme sürecine ilişkin görüşleri ve algıları. Kuramsal Eğitim Bilim Dergisi, 11(4), 718-747. https://doi.org/10.30831/akukeg.392654

Dikmen, M., \& Tuncer, M. (2018). Bilgisayar destekli eğitimin öğrencilerin akademik başarıları üzerindeki etkisinin meta-analizi: Son 10 yılda yapılan çalışmaların incelenmesi. Türk Bilgisayar ve Matematik Eğitimi Dergisi, 9(1), 97-121.

Dinçer, S. (2014). Eğitim Bilimlerinde Uygulamalı Meta-analiz. Pegem Akademi. https://doi.org/10.14527/pegem.001

Dinçer, S. (2015). Türkiye'de yapılan bilgisayar destekli öğretimin öğrenci başarısına etkisi ve diğer ülkelerle karşılaştırılması: Bir meta-analiz çalışması. Journal of Turkish Science Education, 12(1), 99-118.

Dollar, Y. K., \& Tolu, A. T. (2015). My first digital story: A case study with 5th grade Turkish English language learners. ELT Research Journal, 4(3).

Egger, M., Smith, G. D., Schneider, M., \& Minder, C. (1997). Bias in meta-analysis detected by a simple, 
graphical test. $B m j, 315(7109), 629-634$. https://doi.org/10.1136/bmj.315.7109.629

Ertem, İ. S., Çetinkaya, Ö. E., Güllü, E. E., \& Palabıyık, E. (2018). Sınıf Öğretmeni Adaylarının Dijital Çocuk Edebiyatı Ürünü Hazırlama Deneyimlerine Yönelik Görüşleri. Electronic Turkish Studies, 13(27). https://doi.org/10.7827/TurkishStudies. 14384

France, D., \& Wakefield, K. (2011). How to Produce a Digital Story. Journal of Geography in Higher Education, 35(4), 617-623. https://doi.org/10.1080/03098265.2011.560658

Francis, M. F. (2018). Digital storytelling with project-based learning: Engaging high school males in space science to improve academic achievement. Unpublished Doctoral dissertation. Northcentral University.

Gabarre, S., Din, R., \& Gabarre, C. (2011). Digital story telling with mobile phones: An experiment in foreign language teaching. In Conference on Academic Development in Higher Education 2011.

Gömleksiz, M. N., \& Pullu, E. K. (2017). Toondoo ile Dijital Hikayeler Oluşturmanın Öğrenci Başarısına ve tutumlarına Etkisi. Electronic Turkish Studies, 12(32). https://doi.org/10.7827/TurkishStudies.12717

Gözen, G., \& Cirık, İ. (2017). Dijital öykülemenin okul öncesi çocukların sosyal-duygusal davranışlarına etkisi. Elementary Education Online, 16(4). https://doi.org/10.17051/ilkonline.2017.358215

Grgurovic, M., Chapelle, C., \& Shelley, M. C. (2013). A meta-analysis of effectiveness studies on computer $\begin{array}{lllll}\text { technology-supported language } \quad \text { learning. } & \text { ReCALL, } & \text { 25(02), } & 165 .\end{array}$ https://doi.org/10.1017/S0958344013000013

Hedges, L. V., Gurevitch, J., \& Curtis, P. S. (1999). The meta - analysis of response ratios in experimental ecology. Ecology, $\quad 80(4), \quad 1150-1156$. https://doi.org/10.1890/0012-9658(1999)080[1150:TMAORR]2.0.CO;2

Hedges, L., \& Olkin, I. (2014). Statistical methods for meta-analysis. Academic press.

Higgins, J. P., \& Thompson, S. G. (2002). Quantifying heterogeneity in a meta - analysis. Statistics in Medicine, 21(11), 1539-1558. https://doi.org/10.1002/sim.1186

Holt, L. (2011, March). Creating Digital Stories with Scratch to Promote Computational Thinking (pp. 31-32). In Society for Information Technology \& Teacher Education International Conference. Association for the Advancement of Computing in Education (AACE).

Hung, C. M., Hwang, G. J., \& Huang, I. (2012). A project-based digital storytelling approach for improving students' learning motivation, problem-solving competence and learning achievement. Journal of Educational Technology \& Society, 15(4), 368-379.

İnceelli, A. (2005). Dijital hikaye anlatımının bileşenleri. The Turkish Online Journal of Educational Technology, 4(3), 132-142.

Işıtan, S., \& Turan, F. (2014). Çocuklarda Dil Gelişiminin Değerlendirilmesinde Bir Anlatı Analizi Yaklaşımı Olarak Öykü Anlatımı. Eğitim Bilimleri ve Uygulama, 13(25), 105-124.

İşman, A. (2011). Uzaktan Eğitim. Pegem Akademi Yayıncılık.

Kabaran, G. G., Karalar, H., Altan, B. A., \& Altıntaş, S. (2019). Sınıf Öğretmeni ve Sınıf Öğretmeni Adayları Dijital Öykü Atölyesinde. International Journal of Education, 8(1), 235-257.

Kablan, Z., Topan, B., \& Erkan, B. (2013). Sınıf içi öğretimde materyal kullanımının etkililik düzeyi: Bir meta-analiz çalışması. Kuram ve Uygulamada Eğitim Bilimleri, 13(3), 1629-1644. https://doi.org/10.12738/estp.2013.3.1692

Kahraman, Ö. (2013). Dijital hikayecilik metoduyla hazırlanan öğretim materyallerinin öğrenme döngüsü giriş aşamasında kullanılmasının fizik dersi başarısı ve motivasyonu düzeyine etkisi. Yayımlanmamış Doktora Tezi. Balıkesir Üniversitesi, Fen Bilimleri Enstitüsü.

Karataş, B. (2019). Dijital Öykü Kullanımının Sosyal Bilgiler Dersinde Öğrencilerin Akademik Başarı ve Tutumlarına Etkisi. Yayımlanmamış yüksek lisans tezi. Muğla Sıtkı Koçman Üniversitesi, Eğitim Bilimleri Enstitüsü.

Keleş, D. (2018). Öğretmen Adayların Tekno-Stres Incelenmesi: Dijital Hikaye Örneği. Yayımlanmamış Doktora Tezi. Kastamonu Üniversitesi.

Keser, H. (2011). Türkiye'de Bilgisayar Eğitiminde İlk Adım: Orta Öğretimde Bilgisayar Eğitimi İhtisas Komisyonu Raporu. Eğitim Teknolojisi Kuram ve Uygulama, 1(2), 83-94. 
Kordaki, M., \& Kakavas, P. (2017). Digital storytelling as an effective framework for the development of computational thinking skills. EDULEARN, 3-5. https://doi.org/10.21125/edulearn.2017.2435

Korucu, A, T. (2020). Fen Eğitiminde Kullanılan Dijital Hikâyelerin Öğretmen Adaylarının Akademik Başarısı, Sayısal Yetkinlik Durumları ve Sorgulama Becerileri Üzerindeki Etkisi. Kastamonu Education Journal, 28(1), 352-370. https://doi.org/10.24106/kefdergi.3617

Kotluk, N., \& Kocakaya, S. (2017). The effect of creating digital storytelling on secondary school students' academic achievement, self efficacy perceptions and attitudes toward physics. International Journal of Research in Education and Science, 3(1), 218-227.

Kubravi, S. U., Shah, S. O., \& Jan, K. (2018). Digital Story Telling: The Impact on Student Academic Achievement, Critical Thinking and Learning Motivation. International Journal of Research in Engineering, Science and Management, 1(12), 787-791.

Kutlucan, E., Çakır, R., \& Ünal, Y. (2018). Dijital öykü anlatımı ile verilen değerler eğitimine yönelik bir eylem araştırmas1. Kastamonu Eğitim Dergisi, 27(5), 2187-2202. https://doi.org/10.24106/kefdergi.3388

Landry, B. M., \& Guzdial, M. (2006). Learning from human support: Informing the design of personal digital story-authoring tools. Journal of the International Digital Media and Arts Association, 3(1), 106.

Lee, J. (1999). Effectiveness of computer-based instructional simulation: a meta analysis. International Journal of Instructional Media, 26(1), 71.

Li, Q., \& Ma, X. (2010). A meta-analysis of the effects of computer technology on school students' mathematics learning. Educational Psychology Review, 22(3), 215-243. https://doi.org/10.1007/s10648-010-9125-8

Liu, K. P., Tai, S. J. D., \& Liu, C. C. (2018). Enhancing language learning through creation: The effect of digital storytelling on student learning motivation and performance in a school English course. Educational Technology Research and Development, 66(4), 913-935. https://doi.org/10.1007/s11423-018-9592-z

Miles, M. B., \& Huberman, A. M. (1994). Qualitative data analysis: An expanded sourcebook (2nd ed.). Thousand Oaks: Sage Publications.

Miyaji, I. (2012). Effects of creating three kinds of digital storytellings on student attitude. Journal of Modern Education Review, 2(4), 238-259.

Nam, C. W. (2017). The effects of digital storytelling on student achievement, social presence, and attitude in online collaborative learning environments. Interactive Learning Environments, 25(3), 412-427. https://doi.org/10.1080/10494820.2015.1135173

Orhan, A. (2019). The Effect of Flipped Learning on Students' Academic Achievement: A Meta-Analysis Study. Cukurova University Faculty of Education Journal, 48(1). https://doi.org/10.16986/HUJE.2018046755

Orhan, A. T., \& Men, D. D. (2018). Web Tabanlı Öğretimin Fen Dersi Başarısına ve Fen Dersine Yönelik Tutuma Etkisi: Bir Meta Analiz Çalışması. Celal Bayar Üniversitesi Sosyal Bilimler Dergisi, 16(3), $245-284$.

Özerbaş, M. A., \& Öztürk, Y. (2017). Türkçe Dersinde Dijital Hikaye Kullanımının Akademik Başarı, Motivasyon ve Kalıcılık Üzerinde Etkisi. TÜBAV Bilim Dergisi, 10(2), 102-110.

Özkaya, P. G., \& Coskun, M. V. (2019). The effect of understanding phrase-meaning relationship through digital storytelling on academic achievement and retention. Educational Policy Analysis and Strategic Research, 14(3), 200-236. https://doi.org/10.29329/epasr.2019.208.10

Özpinar, İ. (2017). Matematik öğretmeni adaylarının dijital öyküleme süreci ve dijital öykülerin öğretim ortamlarında kullanımına yönelik görüşleri. Bartin Üniversitesi Egitim Fakültesi Dergisi, 6(3), 1189-1210. https://doi.org/10.14686/buefad.340057

Özpinar, İ., Gökçe, S., \& Yenmez, A. A. (2017). Effects of Digital Storytelling in Mathematics Instruction on Academic achievement and Examination of Teacher-Student Opinions on the Process. Journal of Education and Training Studies, 5(10), 137-149. https://doi.org/10.11114/jets.v5i10.2595

Prensky, M. (2001). Digital natives, digital immigrants (part 1). On the Horizon, 9(5), 1-6. https://doi.org/10.1108/10748120110424816

Pürbudak, A., \& Ertuğrul, U. (2019). Bellek Destekli Strateji Yöntemiyle Hazırlanmış Dijital Öykünün Yabancı Dil Dersi Tutumuna Etkisi. Gazi Eğitim Bilimleri Dergisi, 5(2), 95-114.

Ramírez, V. D., \& Alonso, B. I. (2007). Using digital stories to improve listening comprehension with Spanish 
young learners of English. Language Learning \& Technology, 11(1), 87-101.

Robin, B. (2006). The educational uses of digital storytelling (pp. 709-716). In Society for Information Technology \& Teacher Education International Conference. Association for the Advancement of Computing in Education (AACE).

Robin, B. (2009) Digital Storytelling: A Powerful Technology Tool for the 21st Century Classroom. Theory into Practice, 47(3), 220-228. https://doi.org/10.1080/00405840802153916

Robin, B. R. (2016). The power of digital storytelling to support teaching and learning. Digital Education Review, $30,17-29$.

Sancar, T. H., \& Yanpar, Y. T. (2015). Effects of creating digital stories on foreign language education pre-service teachers' TPACK self-confidence. Educational Studies, 41(4), 444-461. https://doi.org/10.1080/03055698.2015.1043978

Schmid, R. F., Bernard, R. M., Borokhovski, E., Tamim, R. M., Abrami, P. C., Surkes, M. A., ... Woods, J. (2014). The effects of technology use in postsecondary education: A meta-analysis of classroom applications. Computers \& Education, 72, 271-291. https://doi.org/10.1016/j.compedu.2013.11.002

Schmid, R. F., Bernard, R. M., Borokhovski, E., Tamim, R., Abrami, P. C., Wade, C. A., ... Lowerison, G. (2009). Technology's effect on achievement in higher education: A Stage I meta-analysis of classroom applications. Journal of Computing in Higher Education, 21(2), 95-109. https://doi.org/10.1007/s12528-009-9021-8

Schwarzer, G. (2007). meta: An R package for meta-analysis. $R$ News, 7(3), 40-45.

Şimşek, B., Usluel, Y. K., Sarıca, H. Ç., \& Tekeli, P. (2018). Türkiye'de Eğitsel Bağlamda Dijital Hikaye Anlatımı Konusuna Eleştirel Bir Yaklaşım. Eğitim Teknolojisi Kuram ve Uygulama, 8(1), 158-186. https://doi.org/10.17943/etku.332485

Tabak, G. (2017). Türkçenin yabancı dil olarak ögretiminde dijital öykü kullanımı. Yayımlanmamış Doktora Tezi. Erciyes Üniversitesi, Eğitim Bilimleri Enstitüsü, Kayseri.

Talan, T. (2019). Dijital Öyküleme Yöntemi İle İlgili Yapılan Çalışmalara Sistematik Bir Bakış. 7. Uluslararası Öğretim Teknolojileri ve Öğretmen Eğitimi Sempozyumu, Antalya.

Tamim, R. M., Bernard, R. M., Borokhovski, E., Abrami, P. C., \& Schmid, R. F. (2011). What forty years of research says about the impact of technology on learning: A second-order meta-analysis and validation study. Review of Educational Research, 81(1), 4-28. https://doi.org/10.3102/0034654310393361

Tatlı, Z., \& Bayramoğlu, A. (2015). Öğretmenlik uygulaması sürecinin dijital öyküler ile yansıtılması. Öğretim Teknolojileri ve Ögretmen Ĕgitimi Dergisi, 4(2).

Tatli, Z., \& Aksoy, D. A. (2017). Yabancı dil konuşma eğitiminde dijital öykü kullanımı. Marmara Üniversitesi Atatürk Eğitim Fakültesi Eğitim Bilimleri Dergisi, January, 137-152. https://doi.org/10.15285/maruaebd.271060

TDK. (2020). Retrieved October 3, 2020, from https://sozluk.gov.tr/ ErişimTarihi

Torun, B. (2016). Ortaokul 6. sınıf hücre konusunda dijital öykü kullanımının öğrenci başarısı, tutumu ve bilimsel süreç becerileri üzerine etkisi. Yayımlanmamış Yüksek Lisans Tezi. Kastamonu University, Institute of Sciences, Kastamonu.

Ünlü, B. (2018). Dijital öykülerle desteklenmiş sosyal bilgiler dersinin öğrencilerin başarısı, kontrol odă̆ ve eleştirel düşünme becerileri üzerindeki etkisi. Yayımlanmamış Yüksek Lisans Tezi, Recep Tayyip Erdoğan Üniversitesi, Sosyal Bilimler Enstitüsü.

Ünlü, B., \& Yangın, S. (2020) Dijital Öykülerle Desteklenmiş Sosyal Bilgiler Dersinin Eleştirel Düşünme Becerisine Etkisi. Recep Tayyip Erdoğan Üniversitesi Sosyal Bilimler Dergisi, 6(11), 1-29. https://doi.org/10.34086/rteusbe.714620

Uslupehlivan, E., Erden, M. K., \& Cebesoy, Ü. B. (2017). Öğretmen adaylarının dijital öykü oluşturma deneyimleri. Uşak Üniversitesi Sosyal Bilimler Dergisi, 10(ERTE Özel Sayısı), 1-22.

Uşun, S. (2004). Bilgisayar Destekli Öğretimin Temelleri. Nobel Yayın Dağıtım.

Wagner, T. (2008). Rigor redefined. Educational Leadership, 66(2), 20-24.

Wolf, F. M. (1986). Meta-analysis: Quantitative methods for research synthesis (Vol. 59). Sage. 
Yang, Y. T. C., \& Wu, W. C. I. (2012). Digital storytelling for enhancing student academic achievement, critical thinking, and learning motivation: A year-long experimental study. Computers \& Education, 59(2), 339-352. https://doi.org/10.1016/j.compedu.2011.12.012

Yıldırım, A., \& Şimşek, H. (2006). Sosyal Bilimlerde Nitel Araştırma Yöntemleri. Seçkin Yayıncılık.

Yılmaz, Y., Üstündağ, M. T., Güneş, E., \& Çalışkan, G. (2017). Dijital hikâyeleme yöntemi ile etkili türkçe öğretimi. Eğitim Teknolojisi Kuram ve Uygulama, 7(2), 254-275. https://doi.org/10.17943/etku.322366

Yoon, T. (2013). Are you digitized? Ways to provide motivation for ELLs using digital storytelling. International Journal of Research Studies in Educational Technology, 2(1), 1-10. https://doi.org/10.5861/ijrset.2012.204

Yüksel, P. (2011). Using digital storytelling in early childhood education: A phenomenological study of teachers' experiences. Unpublished Doctoral Dissertation. Middle East Technical University, Ankara.

Yürük, S. E., \& Atıcı, B. (2017). Dijital öykü temelli değerler eğitimi materyallerinin öğrencilerin değer kazanımına etkisi. Trakya Üniversitesi Ĕ̈itim Fakültesi Dergisi, 7(1), 56-74.

\section{Copyrights}

Copyright for this article is retained by the author, with first publication rights granted to the journal.

This is an open-access article distributed under the terms and conditions of the Creative Commons Attribution license (http://creativecommons.org/licenses/by/4.0/). 